May 2013

\title{
Embedded Librarians and the TEACH Act
}

Anthony N. Burik

San Jose State University, anthonyatslis@gmail.com

Follow this and additional works at: https://scholarworks.sjsu.edu/ischoolsrj

Part of the Library and Information Science Commons

\section{Acknowledgements}

I completed an original version of this paper for a class on digital copyright while enrolled as a graduate student in the School of Library and Information Science at San Jose State University. I would like to thank those who read and commented on the original version of this paper. Any errors that appear in this article, however, are my own.

\section{Recommended Citation}

Burik, A. N. (2013). Embedded Librarians and the TEACH Act. School of Information Student Research Journal, 3(1). https://doi.org/10.31979/2575-2499.030103 Retrieved from https://scholarworks.sjsu.edu/ ischoolsrj/vol3/iss $1 / 3$

This article is brought to you by the open access Journals at SJSU ScholarWorks. It has been accepted for inclusion in School of Information Student Research Journal by an authorized administrator of SJSU ScholarWorks. For more information, please contact scholarworks@sjsu.edu. 


\title{
Embedded Librarians and the TEACH Act
}

\begin{abstract}
Embedded librarians who work in online courses in American post-secondary institutions should embrace the Technology, Education, and Copyright Harmonization Act, or TEACH Act, the federal law that governs online teaching and learning. As embedded librarians take on online instructional assignments, knowledge of TEACH will provide guidance in their role as online instructors. In addition, as they come to a better understanding of TEACH and copyright issues the law covers, based in part on their knowledge of copyright concerns in library-related situations, embedded librarians will have more clarity about the work they can and cannot do in an online environment. Finally, as embedded librarians increase their presence in online classes in varied ways, the embedded librarian position evolves into a version of Bell and Shank's "blended librarian" who serves as both a librarian and educator, and becomes a more valuable member of the academic community. The current lack of discussion about the provisions of the TEACH Act among embedded librarians who write about the work they have done in online courses, however, is a troubling sign. Knowledge of the TEACH Act will help protect embedded librarians and others from copyright infringement and aid in the further development of embedded librarianship.
\end{abstract}

\section{Keywords}

embedded librarian, online courses, online learning, TEACH Act, copyright, blended librarian

\section{Acknowledgements}

I completed an original version of this paper for a class on digital copyright while enrolled as a graduate student in the School of Library and Information Science at San Jose State University. I would like to thank those who read and commented on the original version of this paper. Any errors that appear in this article, however, are my own.

\section{About Author}

Anthony Burik graduated from the MLIS program at San Jose State University in December, 2012. He has an A.B. in History from UC Berkeley and an M.A. in Social Studies Education from Teachers College, Columbia University. He currently works as a distance learning teacher for Mt. Diablo Adult Education in Concord, California. 
One of the most recent developments in the world of libraries is the rise of embedded librarianship. According to Carlson and Kneale (2011), "Embedded librarianship takes a librarian out of the context of the traditional library and places him or her in an 'on-site' setting or situation that enables close coordination and collaboration with researchers or teaching faculty" (p. 167). Embedded librarianship can take place in a number of diverse settings, including workplaces and research institutes, as well as libraries. This paper will explore the case where an academic librarian is embedded in an online course offered at an American post-secondary institution.

The practice of embedding librarians in online college courses is still in its infancy. As evidenced by the literature, embedded librarians, for the most part, offer similar information and services that they provide in physical settings in their face-to-face interactions with faculty members and students. The digital educational environment, however, creates new possibilities for embedded librarians that may not necessarily be available to them in the physical, timebound settings that they are used to. One of those possibilities is the ability to be more of an instructor in the course in which the librarian is embedded, through an arrangement with the course instructor(s) and/or by virtue of the librarian being embedded in the course.

As embedded librarians assume more of a teaching role in online courses, one thing they must consider is the Technology, Education, and Copyright Harmonization Act, known as the TEACH Act, which was enacted into law in 2002 and is codified in the U.S. Copyright Act at 17 U.S.C. $\S \S 110(2)$ and 112(f). The TEACH Act is the preeminent law governing online teaching and distance education. Even though librarians are typically not considered to be teachers and are not specifically mentioned in the TEACH Act, librarians who provide instruction in the online courses in which they are embedded appear to take on this online teaching role and, therefore, fall under the purview of TEACH. Librarians need to understand that the virtual classroom is different from the faceto-face classroom, or they may unwittingly get themselves into trouble by thinking that library instruction that is acceptable in a face-to-face setting is automatically permissible in an online educational environment.

This article will argue that librarians who are embedded in online classes should embrace the TEACH Act for three reasons. The first reason relates to the changing role of the embedded librarian. Based on the work that embedded librarians are doing in the digital environment, and especially with the move toward more online instruction, one could easily ask whether embedded librarians are considered to be librarians or teachers. As embedded librarians create learning objects for the digital environment, teach units within online courses, and build online courses from start to finish, they transcend the librarian role and take on the same kind of instructional assignments that everyday teachers do. Thus, 
since the TEACH Act is meant to provide guidance for the online teacher, the embedded librarian should be familiar with and follow the guidelines spelled out in TEACH.

Second, even though the TEACH Act discusses distance education and online learning, TEACH in large part addresses copyright issues, a subject of primary importance to libraries and librarians. Becoming knowledgeable about the TEACH Act would be a logical extension of the understanding that librarians already have about copyright. If embedded librarians want to make the transition from face-to-face settings to virtual classrooms, they may have to give up some of the practices they rely on as librarians working in person with patrons, but they will also be rewarded with new opportunities by becoming online instructors. These are instances that have to do with whether embedded librarians can use the same materials online that are available to them in the physical library, whether they can provide the same kinds of information and services they do when working with patrons face-to-face, and so on. The key is acknowledging that face-to-face and virtual settings are different and not necessarily bound by the same laws. Knowing the language of TEACH and raising the level of understanding of the law's provisions, coupled with a background in copyright from other instances and experiences that occur within the library, will bring clarity to the work of embedded librarians as they develop online courses, whether in partnership with faculty members or on their own.

Finally, by becoming experts on the TEACH Act, embedded librarians demonstrate how academic librarianship can evolve to address the challenge created by those who question the importance of the library in the life of the university, as other means of obtaining information and assistance, which in the past could be found only in a library, are now available elsewhere. The embedded librarian becomes a version of Bell and Shank's (2004) "blended librarian," who is a vital member of the academic community due to his or her knowledge and skills as both a librarian and an educator. As more of the university's instruction moves online, embedded librarians will be able to advise those who are involved in virtual teaching about what is and is not allowed with regard to copyright. Librarians can provide this vital service to their colleagues in the academic community. Providing this service will help embedded librarians in their quest to take on a new role in the virtual environment and to move the field of embedded librarianship forward.

\section{Literature Review}

For the embedded librarian, it is clear that the educational landscape is changing, presenting new opportunities for library instruction. There is interest among college instructors to include embedded academic librarians in their online 
courses to enhance students' understanding of the research process and to further develop students' research skills. Some embedded librarians are beginning to break out of the narrow confines of the "one-shot" library session, taking on a more formal instructional role in online courses and challenging their own notions of what information and services they could and should be providing. The future looks encouraging for the field of embedded librarianship itself, as distance education continues to grow at many educational institutions, potentially creating a larger demand for this service. Thus, it makes sense to ask to what extent embedded librarians are aware of the TEACH Act and the larger issue of copyright compliance in the virtual classroom. At first glance, the picture does not look promising.

Since passage of the TEACH Act in late 2002, there have been only a handful of articles that specifically address librarians and TEACH. Lipinski (2003) wrote about some of the disturbing implications of TEACH, as well as the Digital Millennium Copyright Act (DMCA) and World Intellectual Property Organization (WIPO) protocols. This new legislation, according to Lipinski, seriously challenged the notion that the balance which had been struck between copyright owners and users over the years, involving access to and use of works in analog formats, would be able to continue in a digital environment with information and content in digital formats. The scales, it now appears, were tipping in favor of owners over users. Allner (2004) wrote that the DMCA and TEACH require that librarians work to ensure that their organizations comply with the law and recommended that all librarians, not just embedded librarians, become familiar with the TEACH Act due to the existence of a networked environment of which the library is a part and through which the library provides services related to distance education. Carter (2007) sought to explain how the library was affected by TEACH and how it could update some of its practices to be in compliance, while also reiterating Allner's point about educating personnel within the organization about the new law. Finally, Irwin (2007) suggested that, although the TEACH Act is silent when it comes to libraries, it is not outside the realm of possibility that the TEACH Act regulates a number of library activities with regard to distance learning, and it may even be to the advantage of libraries to seek inclusion under the provisions of $\mathrm{TEACH}$ in order to explicitly gain certain privileges and clarity under the law. Outside of journal articles, writers such as Crews (2012) have tried to make some of the complicated language of the TEACH Act more accessible to those affected by the legislation, namely educators and librarians.

As researchers and practitioners add to the growing body of literature about embedded librarianship, another opportunity arises in which to view the impact (or, alternatively, non-impact) of the TEACH Act within the field. In this regard, articles, mostly from 2009 to 2012, were reviewed, focusing on three 
themes: descriptions of the experiences of single embedded librarians working in either one course or multiple courses (Hawes, 2011; Held, 2010; Hoffman, 2011; Kealey, 2011; Konieczny, 2010); descriptions of the experiences of an embedded librarian program within a college or university (Edwards \& Black, 2012; Hemmig \& Montet, 2010; Matthew \& Schroeder, 2006; Stewart, 2007; Tumbleson \& Burke, 2010; Wright \& Williams, 2011); and descriptions of the embedded librarian model or best practices within the field (Carlson \& Kneale, 2011; Hoffman \& Ramin, 2010; Sullo, Harrod, Butera, \& Gomes, 2012; York \& Vance, 2009). In all of the reports of the exciting activities in which embedded librarians are involved in online courses and the recommendations on how to structure an embedded librarian program, there is no discussion of the TEACH Act by librarians working in virtual classrooms, and there is only one mention of the consideration of copyright issues. Although this literature review is by no means an exhaustive list of what has been written about embedded librarianship in the last few years, this cross section of articles on the subject raises a concern that so little has been written about librarians and the TEACH Act. In addition, there is little consideration in these articles of the copyright regulations in the TEACH Act that potentially affect embedded librarians involved with virtual instruction. In short, the lack of recognition and discussion of the TEACH Act serves as the basis for the recommendation that embedded librarians embrace TEACH due to its impact on the work of embedded librarians in online courses.

\section{The Role of the Embedded Librarian: Librarian or Teacher?}

Embedded librarians are librarians first and foremost. They are recruited by faculty members or ask faculty to join online courses in order to meet teachers and students where they are - in this case, in the virtual classroom. What happens when embedded librarians work in these courses? Not surprisingly, they end up doing many tasks that librarians typically do in the course of their day in a physical library space. Sullo et al. (2012) looked at 82 questions that were asked in 16 online college classes via discussion boards and email over the course of a year and a half. They categorized the questions in the following way: general research guidance $(34 \%)$, citation questions $(22 \%)$, using library resources $(20 \%)$, off-campus access to library resources (10\%), locating a journal article (7\%), locating a book (1\%), and other (6\%) (pp. 27-29). As a part of her library instruction to students, Kealey (2011) assigned learning outcomes, including such skills as deciding on appropriate databases to use, determining the correct corresponding subject headings from keywords, and combining subject headings and/or keywords with the correct Boolean operators. Held (2010) worked with a faculty member to integrate into an online course video tutorials meant to assist students in the research process. The tutorials covered such subjects as 
developing a topic, evaluating online resources, and using one of the library's most popular databases. These examples demonstrate that embedded librarians are usually involved with the kinds of activities that they are trained to do, even when they move from a physical library to an online setting.

The digital learning environment, however, offers intriguing possibilities. For example, within course or learning management systems (CMSs or LMSs) that colleges and universities use to organize their online courses, embedded librarians have created library "courses" that exist separately from the courses in which they are working. These courses connect students with useful information such as web links, tutorials, and resource guides, which they can draw on for their coursework and which bring the library into the CMS or LMS (Matthew \& Schroeder, 2006; Stewart, 2007). Embedded librarians have also taken on teaching assignments in online courses that go well beyond the "one-shot" session typical of library instruction. Kealey (2011), embedded in a course for physician assistant students, described how, over the course of three semesters, she became responsible for two weeks of instruction and $15 \%$ of the total grade that a student received in the course. Other librarians (Konieczny, 2010; Matthew \& Schroeder, 2006; Sullo et al., 2012) have started using web conferencing software for a variety of purposes: teaching students in remote locations, teaching smaller groups of students at staggered times rather than the whole class at once, and holding office hours.

Shepley (2009) described one possible model for the future of embedded librarianship. As librarians at her college have forged relationships with members of the online course development unit, which includes faculty members, instructional designers, and other personnel, the librarians have increased their participation in courses that have been developed and delivered online. As a result, "what initially began as a traditional reference model has evolved so that librarians are integral members of course development teams and increasingly function as instructors in the online environment" (p. 91). Thus, one can envision some of the possibilities for the future of embedded librarianship. For example, in her capacity as an embedded librarian, Kealey (2011) described her teaching experience, which included designing video lectures and handouts for the students and then using quizzes that she created to assess the students' level of understanding, which any online teacher would recognize as a regular part of course instruction. She also discussed how, as she spent more time serving as an embedded librarian partnering with her faculty member, she was able to further develop the lectures and assessments she used in her courses to correct some of the shortcomings of earlier versions, which is a mark of good instruction. When reviewing the experiences of embedded librarians in general, however, it is clear that most of the relationships that librarians have are only with the faculty members with whom they are collaborating and not with other members of the 
school community. In order to achieve what Shepley described, embedded librarians will have to reach out to others on campus who are involved with online course development if they wish to become more involved in teaching online.

Even if embedded librarians do not take on instructional opportunities similar to Kealey's, though, what happens to the role of the embedded librarian in an online course? Is the embedded librarian a librarian who teaches, or a teacher who also happens to be a librarian? The question is significant because the TEACH Act does not mention libraries or librarians, yet the lines are blurring between online instructors and embedded librarians who are present in the same courses. For example, within an online course in the CMS or LMS, the librarian is typically identified as an Instructor or Teaching Assistant, even if the librarian is not teaching, because everyone within a course has to be assigned a role in order to have access to the course. Although librarians have had to struggle just to get labeled as Instructors in online courses (Hoffman, 2011; Hoffman \& Ramin, 2010; Konieczny, 2010), the Instructor role is the preferred role because it enables a librarian to upload course materials, grade assessments, monitor discussion forums, and work behind the scenes of the course like an instructor. It is also a necessary role in order to develop an independent library "course" within the CMS or LMS. There is no Librarian role, although in at least one case the college was able to create such a role by customizing the CMS (Hoffman, 2011). This oversight by the entities that build the CMS or LMS has created a peculiarity where, within the world of online courses for the time being, participants must be either instructional staff or students.

Irwin (2007) wrote that "librarians often have other roles in education, namely as educators themselves. Because they serve the educational system in more than one way, the legal status of libraries and librarians is complicated" (p. 899). It is important to remember that libraries and librarians are not specifically mentioned in the TEACH Act. The TEACH Act is very educator-focused. That does not mean, however, that librarians who work in online courses are potentially excluded from the reach of the TEACH Act. For example, schools and libraries share a number of important features when it comes to recognizing who may be affected by the TEACH Act. These features include, for example, the legal status of the organization, having policies regarding copyright and the ability to inform about copyright, serving students, being able to instruct using technology, and having potential instructional materials at one's disposal (Crews, 2012). However, it may be that not being mentioned in the TEACH Act has led a number of librarians to believe that the Act has nothing to do with them or to remain ignorant of its provisions. Even if embedded librarians as a group were to make a concerted effort to convince CMS or LMS providers to add a role specifically for them, or work with instructional design staff to see if the CMS or LMS could be customized to include a Librarian role so that they have a unique 
designation within the management system, the fact remains that embedded librarians serve an instructional role within online courses, regardless of the designation they are assigned. Embedded librarians, whether passively or actively, are in the courses to impart their knowledge and skills for the benefit of those taking the courses. An understanding of the TEACH Act, then, is necessary in order to properly do a librarian's job in the virtual classroom.

\section{TEACH, Copyright, and Doing Things Differently}

Allner (2004) put it succinctly: "Academic libraries play a crucial role in providing adequate support for distance education. . . . However, copyright laws may limit a library's ability to provide support" (p. 180). As instruction moves online, the danger, of course, is that embedded librarians assume that the activities they have performed for some time now in a face-to-face environment will carry over into the virtual classroom without any need for adjustment. Like online instructors, embedded librarians should be asking themselves what has changed as the instructional setting shifts.

Crews (2012) pointed out that the TEACH Act has created some new opportunities for including content in distance learning settings that previously was not allowed, particularly in the case of performances of nondramatic literary and musical works, dramatic works, and audiovisual works, as well as displays of any work (p. 87). The TEACH Act, however, has also added a new layer of compliance of which those involved with distance learning must be aware. Complying with the Act would include letting students know that online course materials may be subject to copyright protection, being able to control the retention and further dissemination of course materials, and excluding certain course materials even though they are available in digital format (pp. 85-86, 88). In addition, there are works that are specifically excluded from distance education. For example, if a librarian were in possession of some digital content and were unsure as to how it was made or acquired, and that librarian then chose to upload it to an online course, the use of that material might place the institution in violation of copyright. With the proliferation on the Internet of content that is often difficult to trace back to its creators, or which has passed through the hands of many users who have each changed it for a variety of purposes, embedded librarians must determine whether potentially valuable educational material places the institution at risk of copyright infringement (p. 88).

Even users of legally acquired material are not always shielded from potential litigation. Twice, the University of California, Los Angeles, has prevailed in court cases (UC San Diego Library, 2012) involving the digitizing and streaming in online courses of videos that were purchased from a vendor who then (together with a trade association) challenged the university's usage of the 
videos. One of the central issues in the lawsuits centered on the ability of the university to copy and then to deliver material via its course management system. Another issue had to do with the "portions" of the videos that were used in courses, which is a murky issue within TEACH. Although the prospect of litigation may be daunting to instructors and embedded librarians, it also has the value of clarifying the law and aiding users in knowing what is and is not allowed. Of course, embedded librarians have other means at their disposal for acquiring and using content. They can contact copyright owners directly for permission to use copyrighted works. They can also use material in the public domain or content with Creative Commons licensing that allows them to use the material with few or no restrictions.

Embedded librarians should also not forget the potential applicability of fair use to the activities that they carry out online. Although the TEACH Act is a relatively new legal development, fair use has been around for quite some time, tracing its origins back to mid-nineteenth century American case law and formally codified in the U.S. Copyright Act at 17 U.S.C. $\S 107$ in 1976. Educators and others have relied on fair use to justify their use of copyrighted materials in faceto-face classroom instruction for many years. In this new digital environment, Irwin (2007) wrote that, although TEACH and fair use are two separate and unique copyright principles, there are times when they complement one another and in essence provide double coverage for certain library activities. Furthermore, librarians should still consider a fair use analysis in those cases where TEACH does not apply or its application is not clear.

However, just as distance learning is reshaping the boundaries of education, so too is it causing some copyright owners and users to rethink the relevance of fair use. According to a report by the Digital Media Project (n.d.), even though educators were encouraged to test the limits of fair use in this new educational setting, the people with whom project personnel spoke, including instructors, librarians, administrators, and legal staff, were not as hopeful that they would be able to mount a successful fair use defense in cases involving digital learning activities as they had been in cases centered on the use of copyrighted material in face-to-face classrooms. What gives users pause is the near absence of decisions by the courts (similar to the aforementioned cases involving UCLA) on what is permissible. Perhaps others are of the same mind as Lipinski (2003), who posited that TEACH and other legislation have upset the delicate balance struck over the years between copyright owners and users, tipping the scales in favor of owners. The project authors also noted that, in the course of their research, they had heard about some instances where publishers privately expressed their concerns to university representatives about the electronic distribution of materials used in online courses and how this distribution appeared questionable to them. It is easy to see how all of these factors could create a chilling effect that 
would make educators and embedded librarians less confident in any fair use justification.

An additional complication is the fact that distance education is an institutional endeavor, involving many more people than just instructors and their students. The educational institution negotiates with the CMS or LMS provider to enable online courses at the school, and this eventually brings administrators, instructional designers, faculty members, students, and librarians into the fold. Rather than leaving the burden of copyright compliance to an individual instructor, the institution must now work to ensure that compliance is occurring at a number of different points. For embedded librarians, this means ensuring that copyright is not violated when instructional materials are taken from other websites, creating links to materials on other websites or to the websites themselves, using screen captures, designing tutorials, building library web pages, and allowing individuals to access library materials online (Allner, 2004). As was noted earlier, librarians also assume a portion of the responsibility for ensuring that students are limited in their access to and use of online course materials. Additionally, they must recognize the pressure placed on the institution to guarantee that all of its members comply with current copyright laws and practices. Even before YouTube, Facebook, Twitter, and the rise of social media, Lipinski (2003) put it bluntly soon after the TEACH Act was enacted:

Institutions can no longer turn a blind eye to the extensive uploading, downloading, and printing of course materials that occurs by educators and students in the course of a distance class scenario; uploading, downloading, and printing that administrators know occurs and which at least in some instances is beyond the limits of the copyright law, and arguably beyond the reach of TEACH. (p. 832)

The issues described above would suggest that embedded librarians who begin teaching in an online environment approach their jobs in a different way. They are not, however, starting from the beginning in their understanding of how copyright issues affect their work. Librarians over the years have become experts on copyright in issues involving published and unpublished works, copying, preservation, replacement, interlibrary loan, and copying equipment on library premises. Librarians have a frame of reference in which to incorporate knowledge and interpretation of the provisions of the TEACH Act. Outside of the legal staff, of all the personnel on a university campus who come up against copyright issues on a routine basis, embedded librarians appear best suited to take on a leadership role in ensuring that copyright violations are avoided as online 
course development moves ahead. Adopting this role becomes another way for librarians to support the educational mission of the institutions they serve.

\section{A New Kind of Academic Librarian}

Academic librarianship is in the midst of a soul-searching process. The field faces a variety of challenges, including the continued growth of powerful search engines such as Google and ancillary projects such as Google Books, the pricing of scholarly literature and its effects on the availability and vitality of published research, and the need to ensure access to both analog and digital materials (Darnton, 2010). Librarians at many institutions are trying to determine the best path through this transition to ensure that academic librarianship remains a vital part of university life. The field must evolve to meet the changes occurring in education, technology, the makeup of the student body, accountability, and the profession itself. Richard (2009) wrote that "traditional" academic librarianship, as it has been practiced for some time, is dying, and academic librarianship now becomes whatever the academic librarian does. The academic librarian is not bound to continue providing only a limited range of services in her or his job, but is also free to bring any creative and innovative skills and knowledge to the position in service of patrons and the institution.

Almost a decade ago, Bell and Shank (2004) first proposed their vision of "blended librarianship," their response to the crisis in academic librarianship. The blended librarian is an academic librarian who is able to combine the librarian's research and technical skills with the educator's instructional and technologyrelated abilities and blend them into one position. With this skill set, the blended librarian would be able to better assist faculty members in their work, due to an understanding of pedagogy and instructional design, and enhance both the teaching and learning processes by participating in a new set of activities that otherwise fall outside the work of a typical academic librarian. The embedded librarian of today is becoming a version of the blended librarian. As embedded librarians in numerous institutions take on more of an instructional role within online courses, part of what they potentially have to offer is teaching their institutional colleagues about copyright and the TEACH Act.

There are six principles of blended librarianship (Bell and Shank, 2004), but two are particularly apropos in the case of embedded librarians and their connection with the TEACH Act. The sixth principle is about changing the relationship with instructors in part by helping them incorporate technology and library resources into online courses. In order to provide this help effectively, it stands to reason that embedded librarians must have a basic understanding of the TEACH Act, both to educate faculty members on what is and is not allowable in terms of course content and to ensure that there are no copyright infringements in 
online courses. Avoidance of copyright infringement is an example of the institutional responsibility that now comes with the addition of online courses. Knowledge of TEACH adds a new layer to the partnerships that embedded librarians have with instructors; librarians bring additional expertise to bear in the further development of online courses and add to the courses' value.

The third principle of blended librarianship is about librarians developing programs and classes for patrons. For embedded librarians, this development would include designing stand-alone courses in the university's CMS or LMS to teach students about library products and services. For librarians with no formal teacher training and no online teaching experience, there is much to learn about designing pedagogically sound courses and making them available in the CMS or LMS; part of that learning for the librarian should include acquiring knowledge about the TEACH Act. Fortunately for librarians, outstanding resources exist, such as the website maintained by the Copyright Advisory Office at Columbia University (http://copyright.columbia.edu/copyright/), that give librarians a solid foundation on a range of copyright issues affecting those who work in online courses. Ultimately, understanding the provisions of the TEACH Act is necessary in order to build courses successfully while using materials and resources that do not violate copyright.

In a follow-up article to their 2004 writing on blended librarianship, Shank and Bell (2011) wrote, "For librarians to remain relevant they must be open to adopting new skills, knowledge, and ideas" (p. 109). In the context of blended librarianship, the authors meant new skills, knowledge, and ideas in the areas of instructional design and teaching. New, grander visions of academic librarianship are needed, however, that allow librarians to utilize their particular information and expertise in different ways, form new partnerships with others, assume leadership roles on issues of importance to the institution as a whole, and expand their skill set as Bell and Shank suggest. Embedded librarians who become familiar with the TEACH Act, integrate it into their daily work, and can then teach others about it represent the kind of embedded librarian position that is needed in order to move the field forward and keep academic librarianship vibrant and forward-thinking.

\section{Conclusion}

Embedded librarianship is an exciting new development in both the library and education fields. For librarians embedded in online courses, this role is a new avenue for delivering resources and services to patrons at a point of need. For educators, there are many benefits to having resource specialists like librarians involved in online courses from start to finish: enhanced course development, library instruction, research assistance, and a closer relationship between the 
school and the library. The online learning environment, however, is not the same as the face-to-face classroom. Just as online instructors must reconsider how and what they teach because of the provisions of the TEACH Act, so too must embedded librarians be aware of what is and is not allowed in the virtual classroom.

Issues that involve copyright, inherent in laws such as the TEACH Act, are not always easy to resolve. These matters involve legal writing that nonlawyers are left to attempt to interpret and apply to the situation at hand. Because of their firsthand experience with numerous copyright issues that arise in the course of working in a library, librarians are in an ideal position to comprehend the law and assist in planning for online instruction that avoids copyright infringement. Embedded librarians do not need to go back to a starting point in trying to understand how the provisions of the TEACH Act may affect their work. They should utilize what they already know about copyright in their study of TEACH and integrate information about the law into their practice.

In addition, becoming experts in TEACH is another way for embedded librarians to demonstrate the value they offer as academic librarians in fulfilling the educational mission of the university. Not only do they bring their considerable information-related knowledge and abilities to the online courses in which they work, but they can also serve as resources for the successful development of the courses themselves. As the amount and variety of digital content expands, embedded librarians with knowledge of the TEACH Act will be able to assist their colleagues in selecting materials wisely from what is available for inclusion in virtual classrooms. Through formal and informal professional development opportunities with their colleagues, they also help increase institutional understanding of the law. Sharing this understanding becomes part of the instructional role of embedded librarians, and it moves the embedded librarian closer to a blended librarian role.

When reviewing the work of embedded librarians in numerous cases from the recent past, however, one does not yet see a discussion of how the TEACH Act potentially affects the work that they do. This discussion must begin so that embedded librarians can avoid copyright infringement as they work in a new online environment and so the field of embedded librarianship continues to evolve and thrive. 


\section{References}

Allner, I. (2004). Copyright and the delivery of library services to distance learners. Internet Reference Services Quarterly, 9(3/4), 179-192. doi:10.1300/J136v09n03_13

Bell, S. J., \& Shank, J. (2004). The blended librarian: A blueprint for redefining the teaching and learning role of academic librarians. College \& Research Libraries News, 65(7), 372-375.

Carlson, J., \& Kneale, R. (2011). Embedded librarianship in the research context: Navigating new waters. College \& Research Libraries News, 72(3), 167170.

Carter, H. V. (2007). Why the Technology, Education and Copyright Harmonization Act matters to librarians: Two cheers for the TEACH Act. Journal of Interlibrary Loan, Document Delivery \& Electronic Reserve, 18(1), 49-56. doi:10.1300/J474v18n01_06

Crews, K. D. (2012). Copyright law for librarians and educators: Creative strategies and practical solutions (3rd ed.). Chicago, IL: American Library Association.

Darnton, R. (2010, December 23). The library: Three jeremiads. The New York Review of Books, 57(20). Retrieved from http://www.nybooks.com/issues/2010/dec/23/

Digital Media Project. (n.d.). The digital learning challenge: Obstacles to educational uses of content in the digital age: A foundational white paper. Retrieved from http://cyber.law.harvard.edu/media/files/copyrightandeducation.html

Edwards, M. E., \& Black, E. W. (2012). Contemporary instructor-librarian collaboration: A case study of an online embedded librarian implementation. Journal of Library \& Information Services in Distance Learning, 6(3/4), 284-311. doi:10.1080/1533290X.2012.705690

Hawes, S. L. (2011). Playing to win: Embedded librarians in online classrooms. Journal of Library \& Information Services in Distance Learning, 5(1/2), 56-66. doi:10.1080/1533290X.2011.570560 
Held, T. (2010). Blending in: Collaborating with an instructor in an online course. Journal of Library \& Information Services in Distance Learning, 4(4), 153-165. doi:10.1080/1533290X.2010.528272

Hemmig, W., \& Montet, M. (2010). The "just for me" virtual library: Enhancing an embedded eBrarian program. Journal of Library Administration, 50(5/6), 657-669. doi:10.1080/01930826.2010.488943

Hoffman, S. (2011). Embedded academic librarian experiences in online courses: Roles, faculty collaboration, and opinion. Library Management, 32(6/7), 444-456. doi:10.1108/01435121111158583

Hoffman, S., \& Ramin, L. (2010). Best practices for librarians embedded in online courses. Public Services Quarterly, 6(2/3), 292-305. doi:10.1080/15228959.2010.497743

Irwin, K. (2007). Librarians who TEACH: Expanding the distance education rights of librarians by applying the Technology Education and Copyright Harmonization Act of 2002. Western New England Law Review, 29(3), 875-914.

Kealey, S. (2011). Continual evolution: The experience over three semesters of a librarian embedded in an online evidence-based medicine course for physician assistant students. Medical Reference Services Quarterly, 30(4), 411-425. doi:10.1080/02763869.2011.609046

Konieczny, A. (2010). Experiences as an embedded librarian in online courses. Medical Reference Services Quarterly, 29(1), 47-57. doi:10.1080/02763860903485084

Lipinski, T. A. (2003). The myth of technological neutrality in copyright and the rights of institutional users: Recent legal challenges to the information organization as mediator and the impact of the DCMA, WIPO, and TEACH. Journal of the American Society for Information Science and Technology, 54(9), 824-835.

Matthew, V., \& Schroeder, A. (2006). The embedded librarian program: Faculty and librarians partner to embed personalized library assistance into online courses. Educause Quarterly, 29(4), 61-65. 
Richard, J. (2009). Is (academic) librarianship dead? Partnership: The Canadian Journal of Library and Information Practice and Research, 4(1), 1-2.

Shank, J. D., \& Bell, S. (2011). Blended librarianship: [Re]Envisioning the role of the librarian as educator in the digital information age. Reference \& User Services Quarterly, 51(2), 105-110.

Shepley, S. E. (2009). Building a virtual campus: Librarians as collaborators in online course development and learning. Journal of Library Administration, 49(1/2), 89-95. doi:10.1080/01930820802312821

Stewart, V. D. (2007). Embedded in the Blackboard jungle: The embedded librarian program at Pulaski Technical College. Arkansas Libraries, 64(3), 29-32.

Sullo, E., Harrod, T., Butera, G., \& Gomes, A. (2012). Rethinking library service to distance education students: Analyzing the embedded librarian model. Medical Reference Services Quarterly, 31(1), 25-33. doi:10.1080/02763869.2012.641822

Tumbleson, B. E., \& Burke, J. J. (2010). When life hands you lemons: Overcoming obstacles to expand services in an embedded librarian program. Journal of Library Administration, 50(7/8), 972-988. doi:10.1080/01930826.2010.489002

UC San Diego Library. (2012, November 26). UCLA copyright lawsuit over streaming of videos dismissed - again [Web log post]. Retrieved from https://libraries.ucsd.edu/blogs/newdirections/ucla-copyright-lawsuit-overstreaming-of-videos-dismissed-again/

Wright, L. B., \& Williams, G. H. (2011). A history of the embedded librarian program at Odum Library. Georgia Library Quarterly, 48(4), 7-11.

York, A. C., \& Vance, J. M. (2009). Taking library instruction into the online classroom: Best practices for embedded librarians. Journal of Library Administration, 49(1/2), 197-209. doi:10.1080/01930820802312995 